\title{
Making room for rivers: quantification of benefits from a flood risk perspective
}

\author{
Nathalie E.M. Asselman ${ }^{1, a}$ and Frans Klijn ${ }^{1,2}$ \\ ${ }^{1}$ Deltares, PO Box 177, $2600 \mathrm{MH}$ Delft, The Netherlands \\ ${ }^{2}$ Delft University of Technology, Department TPM, Jaffalaan 5, 2628 BX Delft, The Netherlands
}

\begin{abstract}
Since 1996, the Netherlands has adopted a flood risk management policy based on making more room for the rivers. Currently, the focus in flood risk management is being adapted again, in view of increasing societal vulnerability and foreseeable effects of climate change. In this context, the choice between making more room for the river and/or strengthening embankments is again of major concern. This calls for further quantification of the effectiveness, costs and benefits of all possible measures. Making room for rivers was originally advocated by referring to a reduction of the probability of failure of the embankments and a reduction of the consequences in case of breaching. These arguments still apply, but the effect of making more room for rivers on flood risk has never been properly quantified yet. In this paper we identify three potential risk reducing effects, and quantify their effect for along the Rhine and Meuse Rivers in the Netherlands. We show that lowering the flood levels means smaller flood probabilities, that larger floodplain surface area significantly influences the relationship between discharge and flood level, and that lower flood levels in the river translate into smaller flooding depths and/or flood extent, and thus reduce the consequences of flooding.
\end{abstract}

\section{Introduction}

In the 1990s, the Netherlands experienced two major floods within a few years (December 1993 and January 1995). The floods triggered both a rapid reinforcement of the existing embankments and a policy change with respect to dealing with river floods, i.e. by giving room to the river. Reinforcement of the embankments was implemented after many years of opposition and debate about whether or not and how to reinforce the embankments, as earlier reinforcements had caused large impacts to highly valued natural and cultural landscape features. Giving room to the river avoids the need to strengthen the embankments, or at least decreases the magnitude of the required reinforcement. The policy change - or transition - from strengthening of existing embankments to giving more room to the rivers was thus partly inspired by a re-valuation of natural and cultural heritage.

Other arguments for a room for the river approach related to sustainable flood risk management. Continued raising of the embankments leads to higher flood water levels in the river. In case of failure of the embankments this will result in larger water depths and increased consequences in terms of economic damage or casualties. In response to an increase in the design flood discharges, a programme to make more room for the rivers was therefore implemented between 2006 and 2015.
In 2010 the Delta programme started. The aim of the Delta programme was to develop long-term strategies to minimise flood risk and to ensure sufficient supply of fresh water, while accounting for climate change and socio-economic developments [1]. The Delta Programme consists of nine sub-programmes. Three sub-programmes cover the national level, namely fresh water supply, spatial planning and flood risk management. The latter involves, among other things, an updating of the protection standards as these largely date from the 1960s. As the economic value of the protected land behind the embankments has increased, it was decided to re-valuate these standards. The outcome of the evaluation was that, especially along the major rivers, the protection standards must be raised considerably [2, 3]. The updated protection standards are shown in Figure 1.

The other six sub-programmes of the Delta Programme looked at specific regions. One of those regional sub-programmes was the Delta Programme on Rivers (DPR). The aim of this sub-programme was to develop a long-term strategy to ensure adequate flood risk management in the areas that can be flooded from the major rivers in the Netherlands, while taking into account the updated protection standards, climate change and socio-economic developments. The preferred strategy that was developed by DPR consisted of a combination of dike reinforcement and making more room for the river [e.g. 4, 5].

\footnotetext{
a Corresponding author: nathalie.asselman@deltares.nl
} 


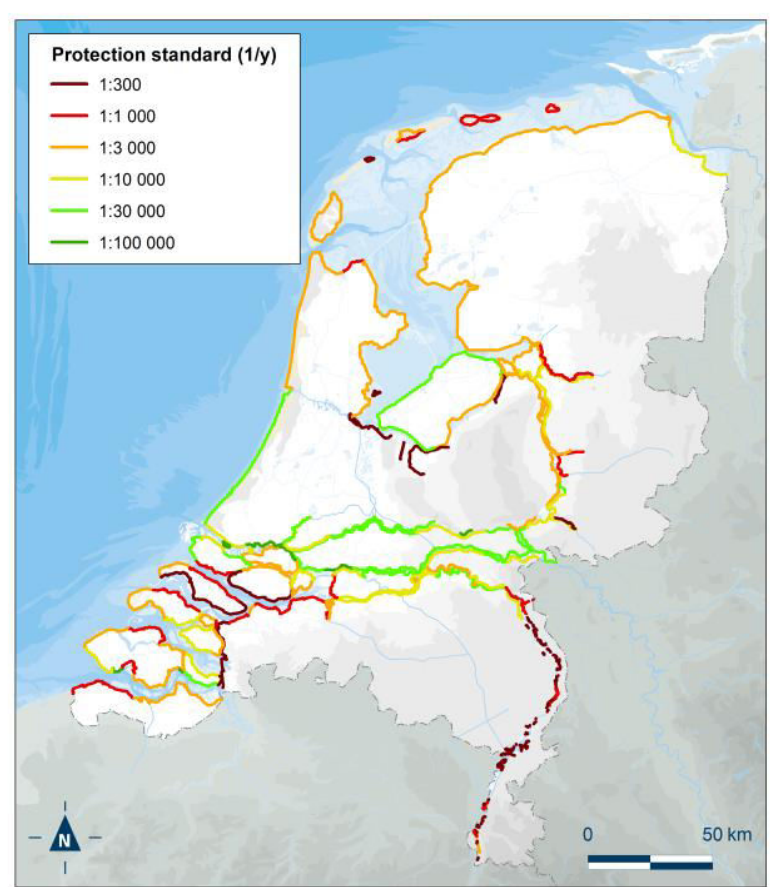

Figure 1. Updated protection standards of the main levees in the Netherlands

Meanwhile, new knowledge on the failure mechanisms seepage and macro-stability revealed that the actual failure probability of the embankments (especially along the major rivers) is much larger than expected. This new knowledge and the raised protection standards both require taking measures. Additional measures are also required to cope with the expected increase in extreme river discharge caused by climate change.

The measures that are required to meet the new protection standards, while accounting for climate change, are such that a strategy consisting of only making more room for the river is not possible. The required lowering of the water level would simply be too much. This was the main reason for DPR to propose a strategy that consists of reinforcement of existing embankments in combination with measures that give room to the river [5]. However, a strategy that consists of a combination of both measures is more expensive than a strategy that only consists of strengthening embankments. This has rekindled the debate about the present policy. Again, the choice between making room for the river and/or levee strengthening is of major concern. A sound and evidenceinformed decision on the implementation of dike reinforcement and room for the river can only be taken when the effectiveness, costs and benefits of these measures are thoroughly understood.

Making room for rivers was originally advocated by referring to:

1. The higher the flood levels in the river, the larger the loading on the defences, the larger the probability of insufficient strength (which might cause moving, slumping, sliding or piping); and

2. The higher the flood levels in the river, the larger the flooding depths, the larger the consequences.
These arguments still stand, but the effect of making room for rivers on flood risk has never been properly quantified yet.

When looking at the impact of making room for the rivers on flood risk, three potential risk reducing effects can be identified:

1. Lowering of the flood water levels means lower probability of overtopping of embankments, and hence lower flood probabilities. The same applies for other failure mechanisms such as piping or macroinstability. In other words, through lowering the water levels during floods, room for the river reduces the failure probability of the embankments.

2. In case the river is given more floodplain surface area (by relocating embankments or making a bypass/floodway), the relationship between discharge and flood level (the Q-h relation) is influenced: the Q-h relation not only lowers but also becomes less steep. This means that any extra discharge volume translates into a smaller rise of the flood water level, which positively affects the probability of breaching of embankments, especially near or above design flood conditions. This primarily affects the sensitivity to uncertainty.

3. When breaching occurs, lower water levels in the river translate into smaller flood depth and/or flood extent, and hence reduce the exposure and consequences of flooding.

\section{Aim}

This paper aims to quantify the benefits of making room for the river from a flood risk perspective. The impact of lower water levels on the failure probability of embankments has first been explored by [6] in 2014 . They computed that $30 \mathrm{~cm}$ of water level lowering would reduce the probability of embankment failure by a factor 2 to 5 . The largest reduction is to be expected for failure resulting from overtopping (a factor 3 on average). The probability of failure due to piping or macro-instability decreased by a factor 2 and 1.5 respectively. Lowering of the water level with $50 \mathrm{~cm}$ can locally reduce the probability of failure by more than a factor 10. Currently, a much more sophisticated study is being carried out by Rijkswaterstaat, Deltares and HKV, which looks in much more detail into the probability of failure and into the required remaining dike reinforcements in case water levels were to be lowered by making room for the river [7]. As this research is still on-going, we have to limit ourselves to the other two risk-reducing aspects: quantification of (1) the differences in the relationship between river discharge and corresponding water levels and (2) the decrease in the consequences of flooding and the resulting reduction in flood risk.

\section{The Rhine and Meuse Rivers}

The Rhine and Meuse Rivers are the largest rivers in the Netherlands. The Rhine has a length of 1320 kilometres and originates in Switzerland. In the Netherlands, the river splits into three major 
distributaries: the Waal, IJssel and Nederrijn-Lek Rivers. The land adjacent to the Rhine distributaries is protected by embankments. The average discharge of the Rhine River is about $2,200 \mathrm{~m}^{3} / \mathrm{s}$. The current design discharge with a probability of exceedence of 1:1250 per year is $16,000 \mathrm{~m}^{3} / \mathrm{s}$. The Meuse River originates in France and has a length of about 900 kilometres. The upstream part of the Meuse River in the Netherlands flows through a natural valley. Embankments were constructed at a limited number of locations to protect individual villages. The downstream part of the Meuse River is embanked over its entire reach. The average discharge of the Meuse River is $230 \mathrm{~m}^{3} / \mathrm{s}$. The design discharge is $3,800 \mathrm{~m}^{3} / \mathrm{s}$.

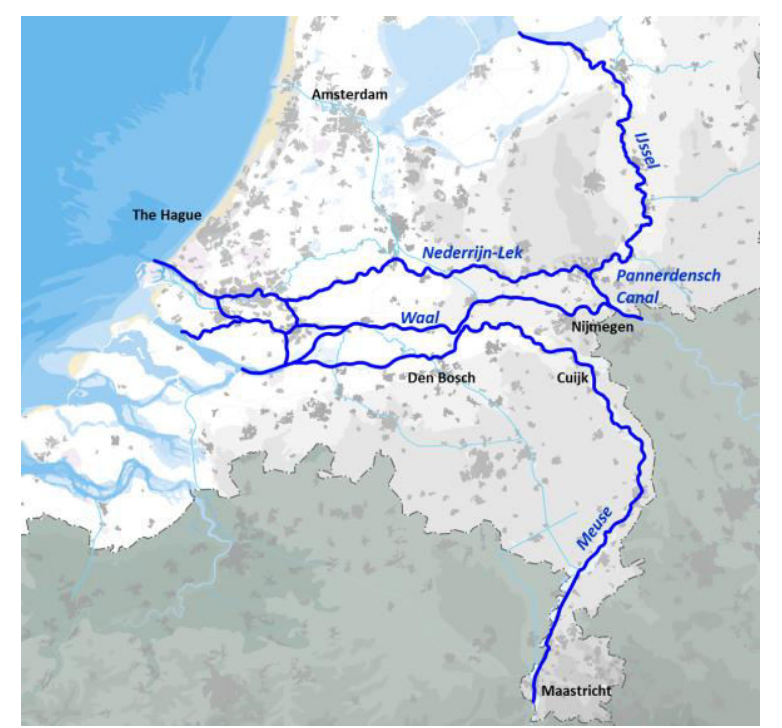

Figure 2. Increase in water level with increasing river discharge in a river with a narrow and one with a wide cross section.

\section{Approach}

This chapter describes the methods that were applied to quantify the effect of making room for the river on (1) the Q-h relationship and (2) flood risk reduction.

\subsection{Q-h relation}

The effect of making room for the river on the relationship between river discharge (Q) and water level (h) was studied in two ways. First, the impact of three different types of measures was studied 'in principle', by using a 1D-hydraulic model of a fictitious river that resembles the Waal River, i.e. the main distributary of the Rhine River in the Netherlands. The fictitious river had a total width of $1500 \mathrm{~m}$. The width of the main channel was $300 \mathrm{~m}$ and the bed level slope equalled $10^{-4}$. The impact of the following types of measures on the Q-h relation was assessed:

- increase in cross sectional area by lowering (part of) the floodplain (in this case lowering of the floodplain by $1 \mathrm{~m})$,

- increase in cross sectional area by increasing the width (relocation of embankments),

- $\quad$ storage of water in detention areas.

Second, the impact of room for the river measures was studied using the results of a $2 \mathrm{D}$ hydraulic model for the actual rivers. As part of the Delta Programme on Rivers (DPR), a 2D WAQUA model was made of the Rhine and Meuse Rivers [8, 9], both for the present situation and for the hypothetical future situation after implementation of the room for the river measures that were proposed in the preferred strategy of DPR. The measures comprised relocation of embankments, bypasses, excavation of side channels and removal of all kind of obstacles. Both models were used to compute water levels under different flood hydrographs. The model results were used to derive $\mathrm{Q}-\mathrm{h}$ relations for a number of locations under present conditions and after having made more room for the river.

\subsection{Flood consequence reduction}

During the last 10 to 15 years, thousands of flooding simulations have been made for different parts of the Netherlands. The simulations were carried out by water boards and Provinces in the Netherlands and by the VNK2 project [10]. The results were stored in a national database so that they can be used for further studies or other purposes. The simulation results were used, amongst other things, to derive the required maps for the European Flood Directive [11], to compute the optimal protection standards for all embankments in the Netherlands [2] and to develop flood hazard maps for spatial planning [12]. Economic damage and number of casualties have been computed for most scenarios in the database using the standard damage model for the Netherlands. As the database contains flooding simulations for two or three different flood levels, the results can also be used to compute the difference in economic damage and numbers of casualties as a function of flood level.

As the embankments in the Netherlands are required to meet the legal protection standards, for our calculations it was assumed that the failure probability equalled the design protection standard. In protected areas, the reduction of the flood risk by lowering the flood levels thus entirely results from a reduction of the consequences (less economic damage and fewer casualties). In unprotected floodplain areas, lower flood levels also affect the frequency of flooding. In these areas, changes in flood risk were computed using (1) changes in economic damage as derived from the simulations in the national database, and (2) changes in flood frequency.

\section{Results}

\subsection{Q-h relation}

The preferred flood risk management strategy developed by DPR contains a large number of measures that make more room for the river. These measures can roughly be divided into three types that involve either: (1) widening of the cross sectional area (for example embankment relocations: set-back or 'managed realignment') (2) deepening of the cross sectional area (for instance by lowering the floodplain or excavation 
side channels) and (3) storage of flood peaks in detention areas.

Theoretically, these measures (1) always result in lower water levels and (2) may result in less steep Q-h relations over the entire range of possible river discharges, or over part of this range. The theoretical effect is illustrated in Figure 3. When the river has little room, a small increase in river discharge $\mathrm{Q}$ will result in a relatively large increase in water level h (upper graph). When the river is given more room by relocation of embankments or by connecting bypasses or floodways, the same increase in river discharge is distributed over a much larger area, which results in a smaller increase in water level (lower graph). The resulting Q-h relation will thus become less steep.

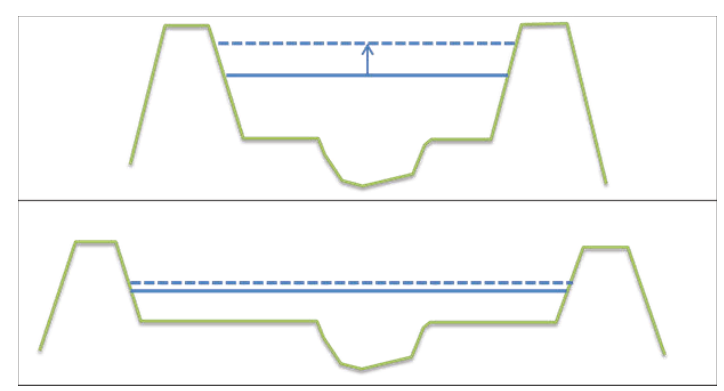

Figure 3. Increase in water level with increasing river discharge in a river with a narrow and one with a wide cross section.

In the Netherlands, embankments are designed by taking into account the probability distribution of various hydraulic loadings (water level, wave impact, rapid level drop, etc.) to cover various relevant failure modes. To account for uncertainties in these hydraulic loadings, a so-called uncertainty allowance (a kind of safety factor) is applied. Above-design floods are more likely to result in breaching when the Q-h relation is steep than when the $\mathrm{Q}-\mathrm{h}$ relation is gentle. This is because in the case of a steep Q-h relation, a relatively small increase in river discharge will result in rapid consumption of the uncertainty allowance. In case of a more gentle Q-h relation, a larger increase in discharge can be handled. It can thus be concluded that measures which reduce the steepness of the $\mathrm{Q}-\mathrm{h}$ relation reduce the failure probability of the embankments and thus the flood risk.

The impact of the three different types of room for the river measures on the Q-h relation as computed with the 1D hydraulic model is shown in Figure 4. The upper graph shows that river widening by relocating the embankments (red line) lowers the water level by about $0.5 \mathrm{~m}$ (on average). The same applies to lowering of the floodplains (green line). The steepness of the Q-h relation, however, differs significantly. In case of embankment relocation, the Q-h relation becomes less steep (red line). This means that the probability of failure during more extreme events increases less sharply when relocations and/or bypasses are applied than when floodplains are lowered or side channels are excavated in the existing floodplain area.

The lower graph of Figure 4 shows the results for detention areas (in red). In this fictitious river, the inflow sill of the detention area was designed in such a way that its effect would be maximal for river discharges of about $7,500 \mathrm{~m}^{3} / \mathrm{s}$. In that specific case the measure would result in a flood level lowering of about $0.5 \mathrm{~m}$. This is similar to the other two measures (embankment relocation and floodplain lowering). However, when the steepness of the $\mathrm{Q}-\mathrm{h}$ relation is looked at, it becomes apparent that detention has little to no effect whatsoever during very high floods. The size of the detention area assumed here is such that it entirely fills up during a flood event. To ensure a maximum effect at a discharge of $7500 \mathrm{~m}^{3} / \mathrm{s}$, inflow into the area starts at relatively low flows. This means that the area is already full when discharges exceed $9,500 \mathrm{~m}^{3} / \mathrm{s}$. As no additional water can be stored during such extreme floods, the lowering of the flood level becomes zero. This results in a very steep upper part of the Q-h relation: even steeper than in the reference situation. This means that from the three measures studied here, detention is the least effective in reducing failure probabilities during extreme events (events that exceed the design conditions, or otherwise deviate from the expected).
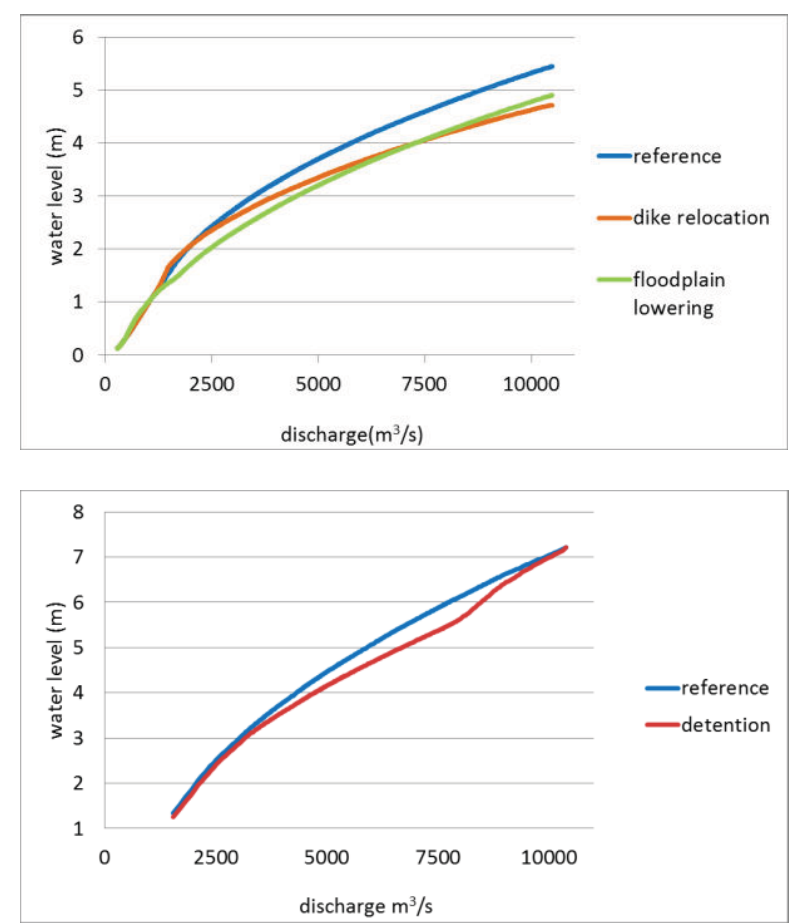

Figure 4. Q-h relations developed for a fictitious river to assess the impact of different types of room for the river measures.

In our second analysis, the impact of room for the river measures as proposed by DPR was assessed from the results of the 2D hydraulic WAQUA models of the Rhine and Meuse River in the Netherlands. Here we show the results for two locations along the river Meuse (Figure 5). For results for a large number of locations we refer to [13].

For the upstream location, measures were proposed that lower the water level by about $2 \mathrm{~m}$ (upper graph in Figure 5). The measures mainly consist of floodplain lowering. One measure that lowers the flood level by $1 \mathrm{~m}$ 
consists of a combination of widening the main channel and lowering the remaining floodplain. The $1 \mathrm{D}$ model for the fictitious river suggested that this kind of measures would result in lower Q-h relations (green line in Figure 4), but with similar steepness as the original one (blue line in Figure 4). This is confirmed by the 2D modelling results for the actual Meuse River, as shown in the upper graph of Figure 5.
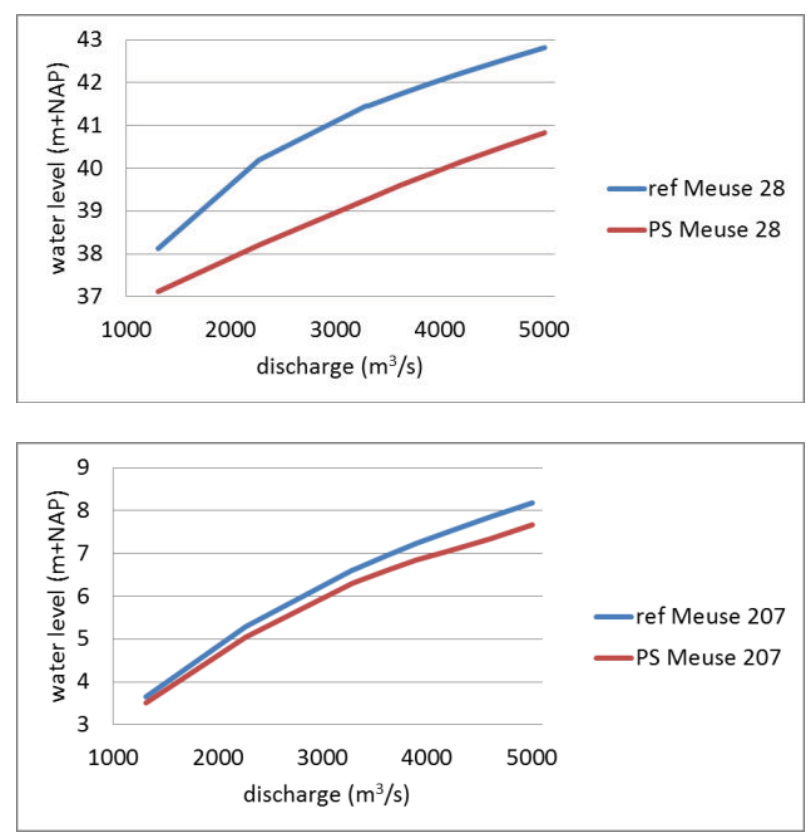

Figure 5. Q-h relations developed for 2 locations along the river Meuse (an upstream location at $\mathrm{km} 28$ near Maastricht and a downstream location at $\mathrm{km} 207$ near Den Bosch) for the present situation (ref) and after implementation of the room for the river measures proposed in the preferred strategy (PS) of DPR.

At the downstream location, the proposed room for the river measures consist of a combination of lowering floodplains and widening the river bed by relocating embankments and connecting bypasses. As can be seen in the lower graph of Figure 5, this results in a Q-h relation that is less steep.

\subsection{Flood consequence reduction}

Making room for the river results in lower flood levels, which in case of breaching of the embankments, mean a smaller hydraulic head over the breach. This in turn results in smaller volumes of water flowing through the breach into the polder, and quite likely even a slower breach growth. The flooding depths in the polder will be smaller and in some cases the flooded area is smaller too. An exceptional example is shown in Figure 6. Figure 6 shows 2 flood maps for a protected area along the Meuse River called "Land van Heusden de Maaskant". In both cases breaching is assumed to occur in the eastern part of the dike ring area (at the yellow dot on the right). In Figure $6 \mathrm{a}$ the flood level in the river is about $80 \mathrm{~cm}$ higher than in Figure $6 \mathrm{~b}$. The total volume of water flowing through the breach is much smaller in the latter case because of (1) the lower water levels in the river and (2) relatively high areas just inland of the breach that are not easily overtopped and cause a backwater effect.

In the majority of the protected areas the impact of lower flood levels in the river is much smaller, however. An example of an area where differences in river flood level have hardly any effect on flood extent and water depth is shown in Figure 7. Both maps show flood extent and water depth caused by a dike breach in the most upstream reach of the Waal River, the main branch of the Rhine River, upstream of the city of Nijmegen. The difference in river flood level is $1.6 \mathrm{~m}$, resulting in flooding depths that are about $1.5 \mathrm{~m}$ lower. But the flooding depths remain very large (more than $4 \mathrm{~m}$ ). As the dike ring is small and relatively low in comparison to the river level during flood, it is entirely flooded in both cases. The lower flood levels in the river do not affect the extent of the flooding either, because the polder is quite flat and delimited by a steep hillside.
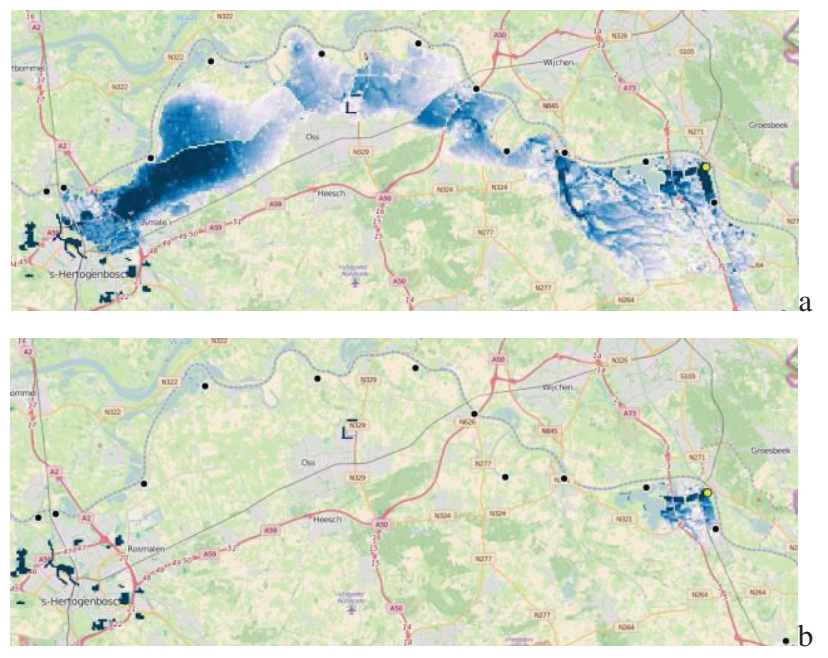

Figure 6. Water depth and flooded area as a function of flood level in the river in case of breaching along the Meuse River near the city of Cuijk. Breaching under design flood level conditions (a) and breaching at water levels that are $0.8 \mathrm{~m}$ lower (b). (source: inundation simulations made for VNK2 and collected by IPO and RWS in the context of the implementation of the EU Flood Directive).

Smaller water depths and flood extents result in less economic damage and fewer casualties. The magnitude of this effect differs from place to place. The largest reduction in consequence per $0.50 \mathrm{~m}$ of water level lowering is to be expected in areas that are not entirely flooded and that are densely populated. Such areas can be found along the Nederrijn-Lek River, but also along the Waal River and the downstream part of the Meuse River (see Figure 8). A red line indicates that economic damage will increase by more than 2 billion euro when breaching occurs when flood levels in the river rise by $0.5 \mathrm{~m}$. 

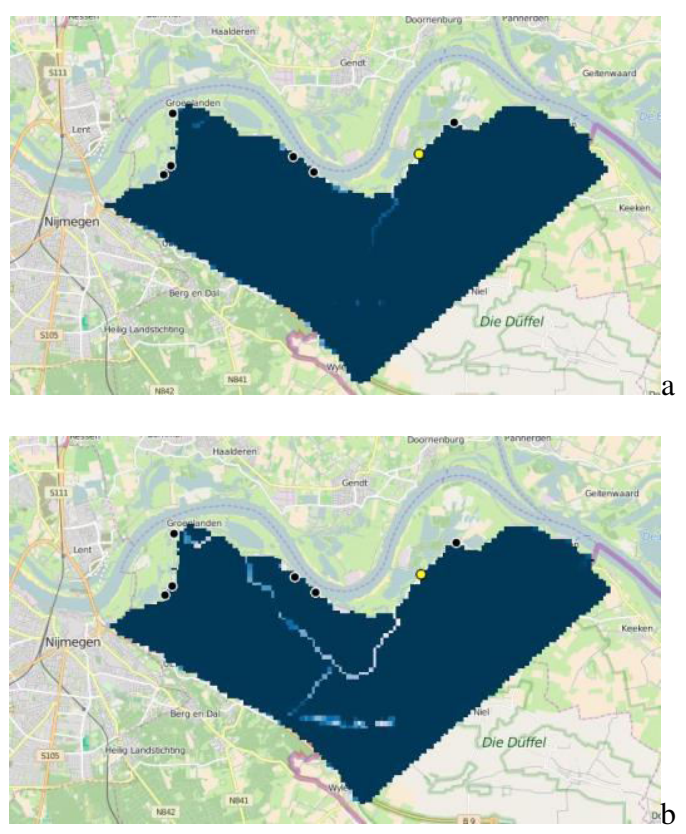

Figure 7. Water depths and inundated area as a function of river water level in case of breaching along the River Waal, upstream of the city of Nijmegen. Breaching under design water level conditions (a) plus $0.8 \mathrm{~m}$ and (b) minus $0.8 \mathrm{~m}$. (source: inundation simulations made for VNK2 and collected by IPO and RWS in the context of the implementation of the EU Flood Directive)

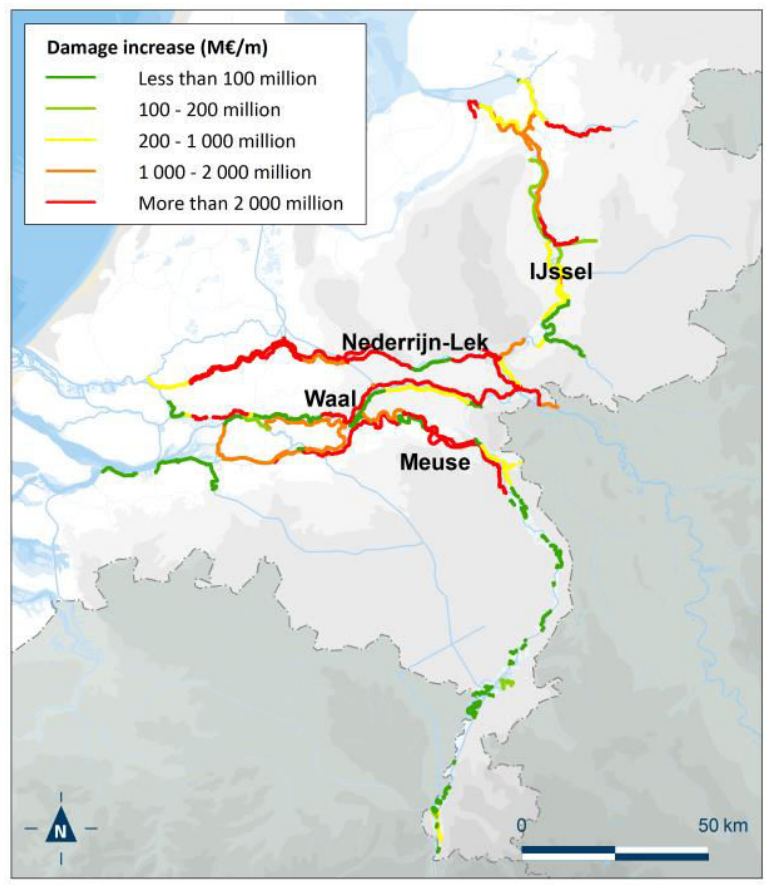

Figure 8. Increase in economic damage due to $0.5 \mathrm{~m}$ higher river flood levels in the river.

A large decrease in economic damage in case of breaching at lower flood levels does not automatically result in a large decrease in flood risk. Flood risk reduction depends, after all, not only on flood consequences, but also on flood probability. As only a limited number of room-for-the-river measures will be implemented during the next two decades, we assumed that most measures that are proposed in the preferred strategy of DPR will be implemented simultaneously with the required reinforcements of the embankments, so that their combination will secure that the new protection standards will be met by 2050 . This means that by the time the room-for-the-river measures will become effective, the failure probability of the embankment will be more or less equal to the new protection standards. Many embankment stretches along the Nederrijn-Lek and Waal Rivers will then have a probability of breaching of less than 1:30,000 per year (see also Figure 1). This means that, although a decrease of 2 billion euros economic damage can be achieved in case of breaching, the flood risk along this dike stretch will only be reduced by about 70,000 euro per year. In many river reaches the reduction will be even less, as the room-for-the-river measures often result in less than $0.5 \mathrm{~m}$ flood level lowering.

The additional flood risk reduction achieved by implementing the room for the river measures that were proposed in the preferred strategy of DPR, on top of what the reduction of flooding probability already achieves, is shown in Table 1. The computed risk reduction varies significantly between the different rivers. As no room for the river measures were proposed for the Nederrijn-Lek River, the additional risk reduction for this river is zero. The largest risk reduction was computed for the upstream part of the Meuse River. This is partly due to the large number of measures proposed, which lower the flood levels by much more than $0.5 \mathrm{~m}$, at several locations even up to $2 \mathrm{~m}$ (see the upper graph in Figure 5) But also, the protection standards for this river reach are much lower, mainly in the order of 1:300 per year. For comparison: protection standards along the downstream part of the Meuse River, and along the Waal and Nederrijn-Lek Rivers are predominantly $1: 10,000$ to $1: 30,000$ per year (see Figure 1). This implies that flood probabilities are up to 100 times smaller along these rivers than along the upstream part of the Meuse River. Finally, this river stretch includes large unprotected areas that benefit considerably from lower flood levels and reduced flood frequencies. The unprotected floodplain areas along the other rivers are small and mainly used as pasture.

\begin{tabular}{|c|c|}
\hline River (Netherlands only) & $\begin{array}{c}\text { Additional risk } \\
\text { reduction (present } \\
\text { value in million euro) }\end{array}$ \\
\hline Pannerdensch Canal \& IJssel & 3 \\
\hline Waal & 60 \\
\hline Nederrijn-Lek & 0 \\
\hline Downstream part of Meuse & 54 \\
\hline Upstream part of Meuse & 656 \\
\hline
\end{tabular}

Table 1. Additional risk reduction (present value) achieved by room for the river measures proposed in the preferred strategy of the Delta Programme [13, 14].

\section{Summary and conclusions}

This paper quantified the effect of making room for the river on the Q-h relation, flood consequences and flood risk. 
Embankments are usually designed to prevent flooding over a given range of hydraulic loadings. When this range is exceeded, for instance during an 'abovedesign' flood, this may lead to breaching. Above-design floods are more likely to result in breaching when the increase in water level per extra amount of discharge is large. This is the case when the Q-h relation is steep; i.e. a relatively small increase in discharge results in a relatively large increase in water level and hence in a relatively large increase in the probability of overtopping, but also in increased likelihood of unstoppable seepage or macro-instability.

This implies that room for the river measures that result in a lower Q-h relation as well as a gentler one are more successful in lowering flood risk under extreme conditions.

Measures that result in a gentler Q-h relation are those that increase the width of the river. Examples are relocation of embankments and connecting bypasses or floodways. Measures that mainly result in lowering of the river bed, such as floodplain lowering, or excavating side channels, are less effective. They lower the $\mathrm{h}$ for each $\mathrm{Q}$, but do hardly affect the slope of the Q-h relation. Detention measures are the least effective in reducing failure probabilities during extreme events, because they only affect the Q-h relation over a limited range of discharges.

Making room for the river lowers flood levels in the river. This results in smaller flooding depths and sometimes also a smaller flood extent in case of breaching. The thus reduced exposure to flooding results in less economic damage and fewer casualties and hence also in reduced flood risk. In case of a $0.5 \mathrm{~m}$ water level lowering, the decrease in economic damage is largest along the Nederrijn-Lek and Waal River and along the downstream part of the Meuse River.

The degree to which the flood risk is reduced, however, not only depends on the reduced consequences (economic damage and casualties), but also on the probability of flooding. This paper showed that, although the potential reduction of the consequences is largest along the Nederrijn-Lek, Waal and the downstream part of the Meuse River, the flood risk reduction is instead largest along the upstream part of the Meuse River. The explanation is that the flooding probabilities of the embanked areas along this river reach are relatively large (protection standards are sometimes 100 times less strict than along the other three rivers) and because this part of the Meuse River has extensive unprotected floodplains and valley bottoms that benefit considerably from lower flood levels and reduced flood frequencies.

It can thus be concluded that a flood risk management strategy that consists of a combination of reinforcing embankments and making more room for the river reduces flood risk further than a strategy of reinforcement only. Flood protection (embankments) combined with flood mitigation (lowering flood levels) is thus the more effective flood risk management strategy. The absolute benefit of this additional flood risk reduction is largest in areas that have a relatively large probability of flooding.

When looking at different types of room-for-the-river measures it can be concluded that measures that increase the width of the river are most effective. They not only reduce flood risk up to and during design discharge conditions (i.e. the range of discharges that the embankments are designed for), but also lower the probability of flooding during unforeseen deviations from these conditions and above-design floods.

\section{References}

1. Van Alphen J. (2014). The Delta Programme and updated flood risk management policies in the Netherlands. Proceedings of the $6^{\text {th }}$ international conference on flood management, PAP014368, September 2014, Sao Paulo, Brazil.

2. Kind J.M. (2014). Economically efficient flood protection standards for the Netherlands. Journal of Flood Risk Management, 7, 103-117

3. Van der Most H., Tánczos I., De Bruijn K.M. and Wagenaar D. (2014). New, risk-based standards for flood protection in the Netherlands. Proceedings of the $6^{\text {th }}$ international conference on flood management, PAP014759, September 2014, Sao Paulo, Brazil.

4. Schielen R.M.J. and Van Aarsen L.F.M. (2014). A strategy for Dutch rivers to handle climate change and new safety standards. Proceedings of the $6^{\text {th }}$ international conference on flood management, PAP014351, September 2014, Sao Paulo, Brazil.

5. Deltaprogramma Rivieren (2014). Hoofdlijnen voorkeursstrategie rivieren: Dijkversterking en rivierverruiming in een krachtig samenspel.

6. Van der Meij, R. and D. Nugroho (2014) Effect van verschillende RvR maatregelen op de faalkans - In relatie tot VTV2006 en OI2014. Deltares report 1209427-000-VEB-0011.

7. Levelt,O., N. Asselman, P. De Grave, W. ter Horst, A. De Kruif, R. Van der Meij, R. Vos, I. Van der Zwan, I. (2015). Uitwerking methode voor bepaling effectiviteit rivierverruiming. Deltares rapport 1220039-000-VEB-0006.

8. Slomp R.M., J.P. de Waal, E.F.W. Ruijgh, T. Kroon, E. Snippen, J.S.L.J. van Alphen (2014). The Dutch Delta Model for policy analysis on flood risk management in The Netherlands. Proceedings of the $6^{\text {th }}$ international conference on flood management, September 2014, Sao Paulo, Brazil.

9. Rijkswaterstaat (2013). User's Guide WAQUA: General Information

10. Jongejan, R., B. Maaskant, W. Ter Horst, F. Havinga, N. Roode and H. Stefess (2013). The VNK2-project: a fully probabilistic risk analysis for all major levee systems in the Netherlands. Proceedings of the International Conference on Flood Management No05, (27/09/2011), Vol. 357, Tokyo, Japan, pp. 75-85.

11. Slager, K. and M. van der Doef (2014) Handboek Overstromingsrisico's op de kaart: Over de methode van kaartproductie voor kaarten. Deltares report 1209425-000-VEB-0002.

12. De Bruijn K. M., Klijn F., Van de Pas B. and Slager C.T.J. (2015). Flood fatality hazard and flood 
damage hazard: combining multiple hazard characteristics into meaningful maps for spatial planning. Nat. Hazards Earth Syst. Sci., 15, 12971309

13. Asselman N., M. Mens and D. Wagenaar (2015) Effect van rivierverruiming op overstromingsrisico en systeemrobuustheid: werking en kwantificering voor Rijn en Maas. Deltares rapport 1220041-000ZWS-0046.

14. Asselman, N. (2014) Strategieën DPR doorgerekend op doelbereik (risicoreductie). Deltares rapport 1209392-000. 